\title{
Profile and Outcome of Supraclavicular Metastases in Patients with Metastatic Breast Cancer: Discordance of Receptor Status Between Primary and Metastatic Site
}

\author{
FABINSHY THANGARAJAH ${ }^{1,2}$, CONSTANZE VOGEL ${ }^{1}$, CAROLINE PAHMEYER $^{1}$, CHRISTIAN EICHLER $^{1,2}$, \\ JOHANNES HOLTSCHMIDT ${ }^{1}$, DOMINIK RATIU ${ }^{1}$, PETER MALLMANN ${ }^{1}$ and WOLFRAM MALTER ${ }^{1,2}$ \\ ${ }^{1}$ Department of Obstetrics and Gynecology, ${ }^{2}$ Breast Center-Department of Obstetrics and Gynecology, \\ Medical Faculty, University Hospital Cologne, Cologne, Germany
}

\begin{abstract}
Background: Breast cancer is a heterogenous and complex disease. A rare site of metastatic breast cancer disease is the neck. Data about supraclavicular metastases in patients with metastatic breast cancer are still lacking. Hence, our study aimed to analyze histological subtypes of supraclavicular metastases compared to the primary site. Materials and Methods: This was a retrospective hospitalbased cohort study of patients with breast cancer who developed supraclavicular metastases. Diagnosis of supraclavicular metastases was confirmed by biopsy or diagnostic lymph node extirpation. Histological subtypes were analyzed and Kaplan-Meier estimates were calculated for overall survival. Results: A total of 20 patients were included in the analysis. The majority of the patients (12/20) had hormone receptor (HR)-positive/human epidermal growth factor receptor 2 (HER2)-negative supraclavicular metastases, disease in 3/20 patients was HR-positive/HER2-positive, HRnegative/HER2-positive in 1/20 patients and basal-like in 4/20 patients. Total discordance rates for estrogen receptor, progesterone receptor and HER2 between primary and metastatic tumors were $20.0 \%, 36.8 \%$ and $29.4 \%$, respectively. The 5-year overall survival was $80 \%$, whereas the 5-year survival after the onset of neck metastasis was 45\%. Conclusion: As a rare site of metastatic breast cancer, supraclavicular metastases are associated with a worse median overall survival from their onset. The high rate of discordance of histological subtype stresses the necessity for biopsies in patients with supraclavicular metastasis.
\end{abstract}

Correspondence to: Fabinshy Thangarajah, University of Cologne, Department of Obstetrics and Gynecology, Kerpener Str. 34, 50931 Cologne, Germany. Tel: +49 22147886545, Fax: +49 22147886546, e-mail: Fabinshy.Thangarajah@uk-koeln.de

Key Words: Metastatic breast cancer, neck metastasis, supraclavicular metastasis, hormone receptor.
Breast cancer is a heterogenous and complex disease (1). Breast cancer can spread to other sites of the body resulting in metastatic breast cancer $(1,2)$. In the course of time, approximately $20-30 \%$ of patients with early breast cancer develop distant metastases and suffer tumor-related death (37). A rare site of metastatic breast cancer is the neck as it accounts for $4 \%$ of patients with metastatic breast cancer $(8$, 9). Neck metastases can be located both in the supraclavicular area and in the upper jugularis level $(8,10)$. The receptor status is known to be an important predictive and prognostic factor and is able to switch in metastatic breast cancer (3).

Whereas lung, bone and liver metastases are usually luminal type of cancer, brain metastases are known to be of the basal type $(11,12)$. Data about supraclavicular metastases in patients with metastatic breast cancer are still lacking. Hence, our study aimed to analyze histological subtypes of supraclavicular metastases compared to the primary site. Of particular interest was the outcome of patients with supraclavicular metastases of breast cancer.

\section{Materials and Methods}

This was a retrospective hospital-based cohort study including unselected patients with breast cancer who developed supraclavicular metastases. Patients were treated between 2013 and 2018 at the University Hospital of Cologne. Diagnosis of supraclavicular metastasis was confirmed by biopsy or diagnostic lymph node extirpation.

The patient charts were analyzed regarding age, therapy and outcome. The histopathological reports were analyzed for estrogen receptor (ER), progesterone receptor (PR) and human epidermal growth factor receptor 2/neu (HER2) expression of the primary tumor and the neck metastases. ER and PR expression were analyzed using the immunoreactive score $(8,13,14)$. HER2 expression was analyzed according to the American Society of Clinical Oncology/College of American Pathologists guideline (8, 14). Strongly positive (3+) cases or those positive by fluorescence in situ hybridization were considered HER2-amplified tumors (8). Hormone receptor-positive was defined as ER- and/or PR-positive. 
Table I. Patient characteristics.

\begin{tabular}{|c|c|c|}
\hline Characteristic & $\mathrm{N}$ & Percentage $(\%)$ \\
\hline Number of patients & 20 & \\
\hline \multicolumn{3}{|l|}{ Age, years } \\
\hline Mean (interquartile range) & $56(21-70)$ & \\
\hline \multicolumn{3}{|l|}{ Chemotherapy } \\
\hline Neoadjuvant & 8 & 40.0 \\
\hline Adjuvant & 12 & 60.0 \\
\hline \multicolumn{3}{|l|}{ Surgery } \\
\hline $\mathrm{BCS}$ & 13 & 65.0 \\
\hline Mastectomy & 5 & 25.0 \\
\hline Unknown & 2 & 10.0 \\
\hline \multicolumn{3}{|l|}{ Axillary surgery } \\
\hline Sentinel node biopsy & 3 & 15.0 \\
\hline Axillary lymph node dissection & 15 & 75.0 \\
\hline Unknown & 2 & 10.0 \\
\hline \multicolumn{3}{|l|}{ Recurrence } \\
\hline Local recurrence & 5 & 25.0 \\
\hline Axillary recurrence & 4 & 20.0 \\
\hline \multicolumn{3}{|l|}{ Primary site } \\
\hline HR-positive/HER2-negative & 9 & 45.0 \\
\hline HR-positive/HER2-positive & 1 & 5.0 \\
\hline HR-negative/HER2-positive & 4 & 20.0 \\
\hline Basal like & 3 & 15.0 \\
\hline Unknown & 3 & 15.0 \\
\hline \multicolumn{3}{|l|}{ Metastatic site } \\
\hline HR-positive/HER2-negative & 12 & 60.0 \\
\hline HR-positive/HER2-positive & 3 & 15.0 \\
\hline HR-negative/HER2-positive & 1 & 5.0 \\
\hline Basal like & 4 & 20.0 \\
\hline Discordance in histological subtype & 9 & 52.9 \\
\hline
\end{tabular}

BCS: Breast-conserving surgery, HR: hormone receptor, HER2: human epidermal growth factor receptor 2 .

Rates of discordance in histological subtype between primary and metastatic sites were analyzed. In addition, localization of further metastases and further treatment were analyzed.

Statistical analysis. Patient characteristics are described using absolute numbers (percentage), mean \pm standard deviation (SD) or median [interquartile range (IQR)], as appropriate. Associations between two qualitative variables were tested using Fisher's exact test. Kaplan-Meier estimates for overall survival were calculated and compared by log-rank test.

Overall survival was defined as the time between diagnosis and death. Patients without an event or who were lost to follow-up were censored. All reported $p$-values are two sided and values of $p<0.05$ were considered statistically significant. As the analyses were regarded as explorative no adjustment for multiple testing was made. Statistical analyses were performed using SPSS 25 (IBM Corp., Armonk, NY, USA).

\section{Results}

A total of 20 patients were included in the analysis. Their mean age was 56 years (range $=26-71$ years). Among the
Table II. Localization of additional distant metastasis.

\begin{tabular}{lcc}
\hline Localization & N & Percentage (\%) \\
\hline Liver & 1 & 5.0 \\
Lung & 2 & 10.0 \\
Bone & 2 & 10.0 \\
CNS & 1 & 5.0 \\
\hline
\end{tabular}

CNS: Central nervous system.

Table III. Further treatment after diagnosis of supraclavicular metastases from breast cancer.

\begin{tabular}{lrc}
\hline Treatment & $\mathrm{N}$ & Percentage (\%) \\
\hline Surgery & 8 & 40.0 \\
Radiation & 8 & 40.0 \\
Chemotherapy & 16 & 80.0 \\
Electrotherapy & 2 & 10.0 \\
Bevacizumab treatment & 8 & 40.0 \\
Anti-HER2-treatment & 6 & 30.0 \\
Endocrine therapy & 13 & 65.0 \\
Other & 4 & 20.0 \\
\hline
\end{tabular}

HER2: Human epidermal growth factor receptor $2 /$ neu.

study cohort, 12/20 patients underwent adjuvant therapy, and $13 / 20$ patients underwent breast-conserving therapy at the time of primary diagnosis. Of the study cohort, 15/20 patients underwent axillary lymph node dissection. A summary of patient characteristics and treatment of primary tumor is presented in Table I.

In total, $5 / 20$ of the patients experienced a local recurrence and $4 / 20$ experienced an axillary recurrence. The mean time from primary diagnosis and diagnosis of supraclavicular metastasis was 7 years (range $=0-21$ years). The hormone receptor rates are given in Table I. Half of the patients had hormone receptor-positive primary disease.

Among the 17 patients with paired receptor status, the discordance rate of histological subtype was $52.9 \%$ (Table I). Total discordance rates for ER, PR and HER2 were $20.0 \%$ $(4 / 20), 36.8 \%(7 / 19)$ and $29.4 \%(5 / 17)$, respectively. Additional distant metastases were detected in liver, lung, bone and central nervous system (Table II). After diagnosis of supraclavicular metastases, patients underwent further therapy as shown in Table III.

In total, 10 patients with neck metastases died (50.0\%) during the follow-up period. The median overall survival after primary diagnosis was 14.0 years (Figure 1), with a 5year overall survival rate of $80 \%$, whereas the median survival duration after the onset of neck metastasis was 3.0 years (Figure 2), with a 5-year survival rate of $45 \%$. 


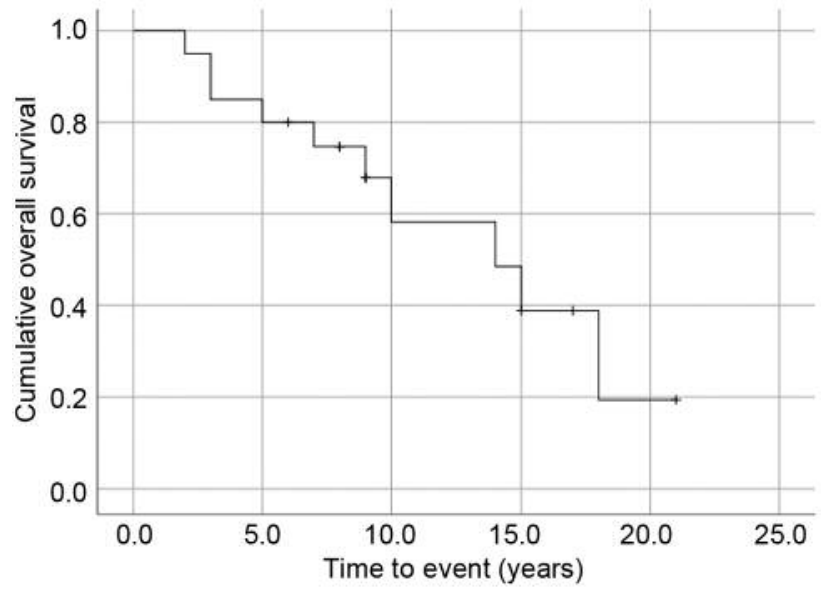

$\rightarrow$ Study cohort
+ censored

Figure 1. Overall survival after primary diagnosis.

\section{Discussion}

In this retrospective analysis, 20 patients with metastatic breast cancer and histologically-proven supraclavicular lymph node metastasis were reviewed.

Median survival of patients with metastatic breast cancer ranges from 2 to 3 years $(15,16)$. For patients with supraclavicular metastases, median overall survival of 86 months after primary diagnosis and 34 months after diagnosis of supraclavicular metastases was reported in a previously published study (8). Surprisingly, median overall survival after primary diagnosis was longer than this in the current analysis, whereas median survival after onset of supraclavicular metastases was similar at 3 years. A reason for the difference in mean overall survival might be the different pattern of oligometastatic disease of the patients analyzed. Discordance of histological subtype (ER, PR, HER2) of primary and metastatic tumors has been discussed in numerous studies since the late 1970s (17-19). Several studies showed an association between discordance of histologic subtype and worse overall survival $(17,19,20)$. The current analysis confirms a high incidence of discordance of histological subtype. The change of PR in particular was observed more frequently than ER change, in accordance with several previous publications (20-23). The treatment of supraclavicular metastases seems to be a challenging medical situation in patients with metastatic breast cancer. Especially, the therapeutic effect of surgical treatment seems to be uncertain (24). Hence, a multimodal approach might be advantageous.

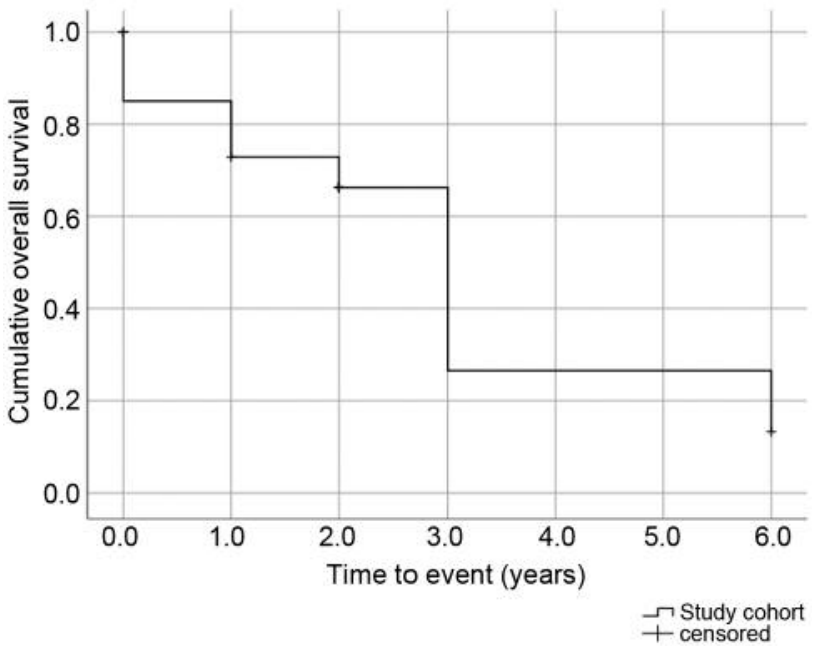

Figure 2. Overall survival after onset of supraclavivular metastases.

\section{Conclusion}

As a rare site of metastatic breast cancer, supraclavicular metastases are associated with a worse median overall survival from their onset. The high rate of discordance of histological subtype stresses the necessity for biopsies in patients with supraclavicular metastasis.

\section{Conflicts of Interest}

The Authors declare that they have no conflict of interest in regard to this study.

\section{Ethical Approval}

All procedures were in accordance with the ethical standards of the Institutional Research Committee and with the 1964 Helsinki declaration and its later amendments or comparable ethical standards.

\section{References}

1 Al-Mahmood S, Sapiezynski J, Garbuzenko OB and Minko T: Metastatic and triple-negative breast cancer: challenges and treatment options. Drug Deliv Transl Res 8(5): 1-25, 2018.

2 Kang Y, Siegel PM, Shu W, Drobnjak M, Kakonen SM, CordónCardo C, Guise TA and Massagué J: A multigenic program mediating breast cancer metastasis to bone. Cancer Cell 3: 537549, 2003.

3 Meng X, Song S, Jiang Z-F, Sun B, Wang T, Zhang S and Wu S: Receptor conversion in metastatic breast cancer: a prognosticator of survival. Oncotarget 7: 71887-71903, 2016. 
4 Chia S, Bryce C and Gelmon K: The 2000 EBCTCG overview: a widening gap. Lancet 365: 1665-1666, 2005.

5 Early Breast Cancer Trialists' Collaborative Group (EBCTCG), Davies C, Godwin J, Gray R, Clarke M, Cutter D, Darby S, McGale P, Pan HC, Taylor C, Wang YC, Dowsett M, Ingle J and Peto R: Relevance of breast cancer hormone receptors and other factors to the efficacy of adjuvant tamoxifen: patient-level metaanalysis of randomised trials. Lancet 378: 771-784, 2011.

6 Dowsett $\mathrm{M}$ and Folkerd E: Deficits in plasma oestradiol measurement in studies and management of breast cancer. Breast Cancer Res 7: 1-4, 2005.

7 Berry DA, Cronin KA, Plevritis SK, Fryback DG, Clarke L, Zelen M, Mandelblatt JS, Yakovlev AY, Habbema JDF and Feuer EJ: Effect of screening and adjuvant therapy on mortality from breast cancer. N Engl J Med 353: 1784-1792, 2005.

8 Nauroth A, Kalder M, Rössler M, Wichmann G, Dietz A and Wiegand S: Conversion of hormone and HER-2 receptor in metachronous neck metastases from breast carcinoma. J Cancer Res Clin Oncol 143: 1811-1814, 2017.

9 Sproson EL, Herd MK, Spedding A V., Brennan PA and Puxeddu $\mathrm{R}$ : Treatment of breast adenocarcinoma metastasis to the neck: Dedifferentiation of the tumor as suggested by hormone markers. Head Neck 34: 1095-1099, 2012.

10 Sesterhenn AM, Albert US, Barth PJ, Wagner U and Werner JA: The status of neck node metastases in breast cancer-Locoregional or distant? Breast 15: 181-186, 2006.

11 Yersal O and Barutca S: Biological subtypes of breast cancer: Prognostic and therapeutic implications. World J Clin Oncol 5: 412-424, 2014.

12 Soni A, Ren Z, Hameed O, Chanda D, Morgan CJ, Siegal GP and Wei S: Breast Cancer Subtypes Predispose the Site of Distant Metastases. Am J Clin Pathol 143: 471-478, 2015.

13 Remmele W and Stegner HE: Recommendation for uniform definition of an immunoreactive score (IRS) for immunohistochemical estrogen receptor detection (ER-ICA) in breast cancer tissue. Pathologe 8: 138-140, 1987.

14 Wolff AC, Hammond MEH, Schwartz JN, Hagerty KL, Allred DC, Cote RJ, Dowsett M, Fitzgibbons PL, Hanna WM, Langer A, McShane LM, Paik S, Pegram MD, Perez EA, Press MF, Rhodes A, Sturgeon C, Taube SE, Tubbs R, Vance GH, van de Vijver M, Wheeler TM and Hayes DF: American Society of Clinical Oncology/College of American Pathologists guideline recommendations for human epidermal growth factor receptor 2 testing in breast cancer. J Clin Oncol 25: 118-145, 2006.

15 Lobbezoo DJA, van Kampen RJW, Voogd AC, Dercksen MW, van den Berkmortel F, Smilde TJ, van de Wouw AJ, Peters FPJ, van Riel JMGH, Peters NAJB, de Boer M, Peer PGM and TjanHeijnen VCG: Prognosis of metastatic breast cancer: Are there differences between patients with de novo and recurrent metastatic breast cancer? Br J Cancer 112: 1445-1451, 2015.

16 Cardoso F, Costa A, Norton L, Cameron D, Cufer T, Fallowfield L, Francis P, Gligorov J, Kyriakides S, Lin N, Pagani O, Senkus E, Thomssen C, Aapro M, Bergh J, Di Leo A, El Saghir N, Ganz PA, Gelmon K, Goldhirsch A, Harbeck N, Houssami N, Hudis C, Kaufman B, Leadbeater M, Mayer M, Rodger A, Rugo H, Sacchini V, Sledge G, van't Veer L, Viale G, Krop I and Winer E: 1st International consensus guidelines for advanced breast cancer (ABC 1). The Breast 21: 242-252, 2012.
17 Aurilio G, Disalvatore D, Pruneri G, Bagnardi V, Viale G, Curigliano G, Adamoli L, Munzone E, Sciandivasci A, De Vita F, Goldhirsch A and Nolè F: A meta-analysis of oestrogen receptor, progesterone receptor and human epidermal growth factor receptor 2 discordance between primary breast cancer and metastases. Eur J Cancer 50: 277-289, 2014.

18 Bogina G, Bortesi L, Marconi M, Venturini M, Lunardi G, Coati F, Massocco A, Manfrin E, Pegoraro C and Zamboni G: Comparison of hormonal receptor and HER-2 status between breast primary tumours and relapsing tumours: clinical implications of progesterone receptor loss. Virchows Arch 459: 1-10, 2011.

19 Ongaro E, Gerratana L, Cinausero M, Pelizzari G, Poletto E, Giangreco M, Andreetta C, Pizzolitto S, Di Loreto C, Minisini AM, Mansutti M, Russo S, Fasola G and Puglisi F: Comparison of primary breast cancer and paired metastases: biomarkers discordance influence on outcome and therapy. Future Oncol 14: 849-859, 2018.

20 Dieci M V, Barbieri E, Piacentini F, Ficarra G, Bettelli S, Dominici M, Conte PF and Guarneri V: Discordance in receptor status between primary and recurrent breast cancer has a prognostic impact: A single-institution analysis. Ann Oncol Off J Eur Soc Med Oncol 24: 101-108, 2013.

21 Liedtke C, Broglio K, Moulder S, Hsu L, Kau S-W, Symmans WF, Albarracin C, Meric-Bernstam F, Woodward W, Theriault RL, Kiesel L, Hortobagyi GN, Pusztai L and Gonzalez-Angulo AM: Prognostic impact of discordance between triple-receptor measurements in primary and recurrent breast cancer. Ann Oncol 20: 1953-1958, 2009.

22 Amir E, Clemons M, Purdie CA, Miller N, Quinlan P, Geddie W, Coleman RE, Freedman OC, Jordan LB and Thompson AM: Tissue confirmation of disease recurrence in breast cancer patients: Pooled analysis of multi-centre, multi-disciplinary prospective studies. Cancer Treat Rev 38: 708-714, 2012.

23 Lower EE, Khan S, Kennedy D and Baughman RP: Discordance of the estrogen receptor and HER-2/neu in breast cancer from primary lesion to first and second metastatic site. Breast Cancer 9: 515-520, 2017.

24 Nikpayam M, Uzan C, Rivera S, Delaloge S, Cahen-Doidy L, Giacchetti S, Espié M and Groheux D: Impact of radical surgery on outcome in locally advanced breast cancer patients without metastasis at the time of diagnosis. Anticancer Res 35: 17291734, 2015.
Received August 27, 2018

Revised September 11, 2018

Accepted September 12, 2018 